\title{
SUCCESSION OF VEGETATION IN ALLUVIAL FLOODPLAINS AFTER EXTREME FLOODS
}

\begin{abstract}
T. C h u m a n, Z . Li p s ký, T. M a t ěj č e k: Succession of vegetation in alluvial floodplains after extreme floods. - Geografie-Sborník ČGS, 111, 3, pp. 314-328 (2006). The paper deals with the topic of vegetation changes and successional developments as well as spread of invasive species in alluvial plains after extreme floods. The issue has become topical in Czechia after several extreme floods concentrated in the last 10 years. The paper is based on the search of the Czech and foreign literature as well as authors own experience and research after catastrophic summer floods in 1997 and 2002 in Czechia. The attention is paid to processes and mechanisms of vegetation succession and regeneration after floods. Floods are functioning as important natural disturbances increasing both geodiversity and biodiversity in the riverine landscapes. Different successional stages as well as variable habitats create a varied mosaic of vegetation and cause high species and ecosystem biodiversity in floodplains. On the other hand the disturbance regime of floods is particularly favorable also for invasive species that spread rapidly through floodplain. While future spatial distribution and spread of invasive species is difficult to forecast, the processes of succession and regeneration of vegetation after floods as well as changes in species composition of communities are predictable and confirm basic ecological principles. KEY WORDS: floods - floodplains - vegetation - succession - invasive species.
\end{abstract}

The presented research was funded by the Research Plan MSM 0021620831 "Geographical Systems and Risk Processes in Context of Global Changes and European Integration" of the Czech Ministry of Education and Research Project VaV-SM/2/57/05 "Long-term changes of river ecosystems in floodplains affected by extreme floods" of the Ministry of Environment of the Czech Republic which is fully appreciated by the authors.

\section{Introduction}

Floodplains represent complex, naturally fragmented ecosystems dependent on the influence of natural disturbance regimes (like floods, erosion and sedimentation), climatic factors and/or ways of present as well as historical land use not only in the floodplain but in the whole catchment. Therefore alluvial floodplains along water courses serve as an excellent example of the geographical continuum (Kolejka 2003). In addition, they belong to the youngest, the most dynamic and changeable segments of the landscape. Fast and extensive changes in alluvial floodplains concern both natural and cultural (land use changes and management) processes. The extreme rate and intensity of geomorphological processes like erosion, transport and sedimentation are accompanied by biotic processes of succession, colonization and migration. Floodplains are used as extremely important biocorridors by plant and animal species for their movement and migration but also as spaces where invasive species are spreading in the landscape. Their distribution is generally facilitated by natural as well as 


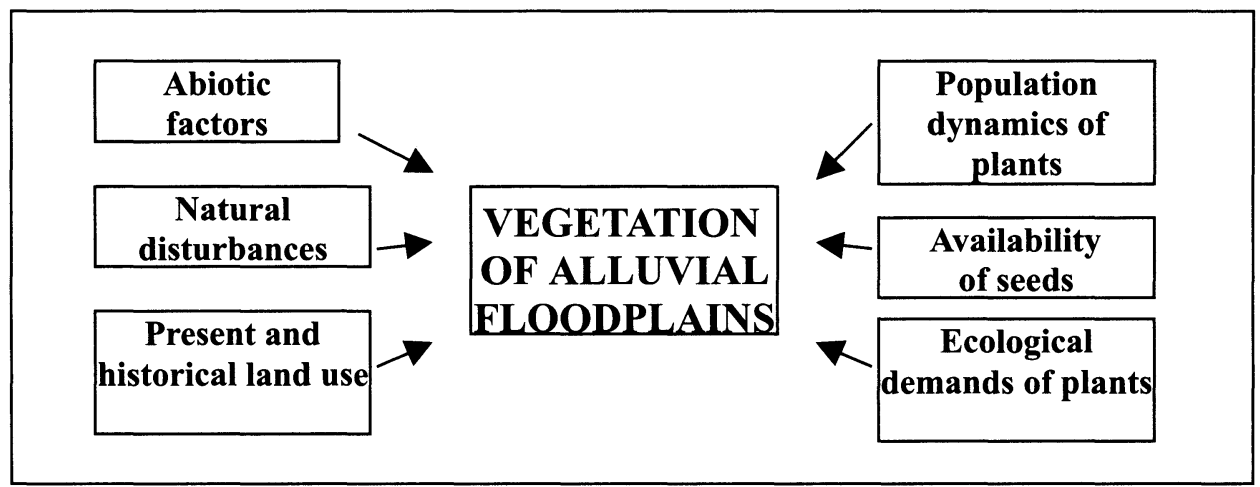

Fig. 1 - Factors influencing vegetation in floodplains

anthropogenic disturbances, which erode the ecosystems, disturb their continuity and create new habitats often occupied by invasive species. Largescale disturbances like floods are an important factor driving the dynamics of the whole floodplain ecosystem.

Catastrophic floods in July 1997 in Moravia and in August 2002 in Bohemia started up many case studies investigating vegetation changes and developments in alluvial plains after floods (Blažková 2003; Koutecký 2000; Kováŕ 1998; Kovář et al. 2002a; Lacina et al. 1998 etc.). Floodplains as areas periodically disturbed by erosion and sedimentation represent a kind of large-scale field laboratories making possible to follow up processes of natural succession, colonization on new created and disturbed surfaces, changes in species composition of communities and other ecological processes in the landscape.

\section{Vegetation of alluvial plains and roots of its high geo/biodiversity}

The state and development of vegetation in alluvial floodplains depend, beside the processes and factors mentioned above, on seeds and spores availability, population dynamics of species and their ecological demands. Relations among the dynamics of the water course, its hydrological parameters and dynamics of the development of vegetation in alluvial plains have been proved by many research activities carried out in different geographical conditions covering diverse water regimes throughout the world (Salo et al. 1986 - Amasonia; Marston et al. 1995 - Western Europe; Hupp, Osterkamp 1996 - United States; Townsend 2001 - United States and Western Europe; Petit, Froend 2001 - Australia; Thoms et al. 2005 - Australia; Schnitzler et al. 2005 - Western Europe and United States; Meyer 2001 - United States and others).

In alluvial plains along water courses, where periodical floods occur, the vegetation cover is composed of a mosaic of transient stages from more to less stable formations. The extent and proportion of areas with specific vegetation stages are a result of flood frequency and kinetic energy of every flood (fig. 1).

In lowlands of the temperate zone, regardless of the human influence, the vegetation in alluvial plains along water courses most likely develops from herbaceous vegetation of early successional stages on young fluvial deposits across stages of shrub vegetation to inundated floodplain forests representing 
final climax community. Because regular yearly floods have only small kinetic energy in this part of alluvial plain under forest vegetation, no significant morphological changes take place on the surface of the floodplain. Montane and submontane rivers power with significantly higher kinetic energy. Large amounts of matters like gravel and stone are yearly transported in their alluvial plains which lead to mechanical defects and injuries of plant individuals; some individuals are buried under the layer of the young sediment deposits. Succession of vegetation is not only one-sided in such dynamic environment and a varied mosaic of habitats with different successional stages of vegetation is formed here. Single successional stages are periodically disturbed and new succession is initiated. It is a reason why mature or even climax successional stages with old trees are not occured here. The absence of trees in alluvial plains along rivers with often occurring and heavy floods is mentioned by Kenyon, Rutherfuer (1999) and Petit, Froend (2001) from Australian rivers or by Meyer (2001) from the Yellowstone National Park. In spite of geographical differences among studied areas, the results confirm the fact the intensive changes of the river channel and floodplain inhibit the growth of tree species in the area affected by the disturbance regime.

Native floodplain forests have been limited by man activities in their original extent and changed into agricultural lands. Primary woody vegetation has been replaced by herbaceous vegetation of alluvial meadows. The meadows represent the vegetation of permanent grasslands created by regular agricultural activities (grazing or mowing grass) on localities with regularly repeated floods and high level of groundwater. Alluvial meadows with many rare species are an important factor increasing biodiversity of the landscape. High biodiversity of plants in alluvial floodplains is a significant feature especially in landscapes with mineral poor grounds where species rich vegetation contrasts with species poor vegetation in the surroundings.

The biodiversity of alluvial vegetation, both floodplain forests and alluvial meadows, is a reflection of different geographical, ecological and historical factors (Salo et al. 1986; Amoros et al. 1987; Schnitzler et al. 2005). According to Krahulec (1996), the factors of biodiversity can be divided in to following groups:

I. Geographical factors are demonstrated especially in phytogeographical differences amongst single regions which are characterized by a specific species composition. The species composition is conditioned by geographical factors namely the altitude (above sea level), slope inclination and orientation (influence on shading, frequency and length of climatic inversions, soil moisture and air humidity) and geological characteristics. Morphological diversity of the surface of the alluvial plain plays an extremely important role increasing the biodiversity as well. It concerns especially various terrain depressions and incised meanders which increase geodiversity of the environment in floodplains and cause the existence of different successional stages of vegetation. Diversity of vegetation is further supported by active dynamics of the water course and floods creating, disturbing and remodelling existing fluvial forms of relief and supporting such a creation of a heterogeneous mosaic of different habitats (Krahulec 1996; Amoros et al. 1987; Salo et al. 1986). Even very low altitudinal differences cause large differences in the frequency of flooding of the surface. On the other hand, according to Marston (1995), extreme floods and extremely high dynamics of water course, which is typical for wild mountain rivers, can effectively disturb successional stages of vegetation and inhibit successional development and 
that way decrease the biodiversity. Marston (1995) demonstrates these effects on the example of the river Snake in the Grand Teton National Park but we can find similar situations in Europe for example in the Alps as well. Common knowledge of landscape ecology concerning the different role of small and big disturbances in the landscape and their influence on biodiversity (Forman, Godron 1993) is so confirmed.

II. Frequency, intensity and duration of floods have influence on processes of erosion and accumulation, transport of seeds and spores and elimination of species which do not tolerate long-term flooding. Physiological mechanisms allowing plants to survive during long-term flooding belong to the most important adaptions we can find in the vegetable kingdom. Some species have even adapted their phenological phases to regular floods. So Australian species Eucalyptus camaldulensis, Melaleuca leucadendra and Eucalyptus rudis or some species of the genera Salix and Populus in the North America have timed to discharge seeds just in the flood period. Seeds have assured optimal moisture regime and minimum competition of other species this way (Pettit, Froend 2001). But these adaptations are possible only at species growing on regularly flooded sites. Intensity of floods, especially the force of water flow, erosion and accumulation have also influence on creation of new open surfaces without vegetation which are colonisated by species not able to survive in a closed stand. Transport of seeds and spores is very important factor influencing the species composition of vegetation on these new surfaces.

III. Species biodiversity is negatively influenced by dominants. Communities without significant dominants are richer and more varied as to species composition in comparison with communities with one dominant species. On the other hand, the existence of more monodominant stands contributes to higher diversity among communities (Krahulec 1996).

$I V$. Occurence of large mammals contributes to higher biodiversity in alluvial plains along rivers as well. On the example of beaver is demonstrated how mammals increase the general diversity of sites on local level. Rather drier sections are concentrated under beaver dam while wet habitats with swamp vegetation are above the dam and the best conditions for heliophilous species are created in the area of the dam (Krahulec 1996).

$V$. Historical factors, namely increasing anthropogenic pressure on the landscape: deforestation changing water regime, frequency and intensity of floods, regulation of water courses, construction of dams, mill-races and other artificial channels, frequency and time of grass mowing, fertilizing, tillage, drainage, ground water withdrawal etc.

\section{Floodplain vegetation and its reaction to extreme floods}

As mentioned above floods are natural and important disturbances that drive the whole floodplain ecosystem. Floods eliminate species that are not adapted to flooding in terms of lack of oxygen and mechanical destruction by transported material. On the other hand floods support less competitive species and are essential for native floodplain vegetation.

Duration and timing together with flood energy are crucial ecological factors controlling floodplain vegetation. Floods during non-growing season affect floodplain vegetation less severely than floods during growing season. Moreover floods during growing season bring a large amount of seeds and affect the spread of species along the stream. 
Extreme floods can negatively influence also floodplain vegetation that is adapted to every year flooding. According to Townsend (2001) variation in flood energy and flood duration even the occurrence of extreme floods are likely to be important ecological factors controlling floodplain vegetation. In case of any alteration to hydrological regime of a particular stream, such as river regulation, the number of floods decreases and floodplain vegetation is becoming less diverse in favor of more competitive species due to more stable and less humid environment. These vegetation communities are afterwards less likely or unable to survive sudden extreme flood therefore the effect of extreme flood is more damaging and the regeneration of vegetation is slower.

In Czechia the vegetation succession and changes of species composition were studied after extreme floods in the Orlice river floodplain by Kopecký already in 1965. The following articles were published after extreme floods in 1997 in the Orlice river floodplain (Kovář 1998; Koppová 2001; Janoušková 2001), Morava river floodplain (Koutecký 2000, 2003), Bečva river floodplain (Lacina et al. 1998) and after extreme floods in 2002 in the Berounka river floodplain (Blažková 2003) and in several floodplains in South Bohemia (Vaněček 2005). The published results together with our own field research of vegetation dynamics after floods can be summarized and divided into three thematic groups:

- regeneration of floodplain vegetation

- vegetation succession on new sites and on agricultural land abandoned due to floods

- the spread of invasive species in the floodplain.

\subsection{Regeneration of floodplain vegetation}

Kopecký (1969) as well as Balátová-Tučková (1996) and Koutecký (2000, 2003) studied the regeneration of herbaceous floodplain vegetation after extreme floods. They identically concluded that regeneration of floodplain vegetation affected by floods is completed within 2 years depending on the flood impact. According to Koutecký (2000, 2003) even after long term flooding when almost all herbs died down in the Morava river floodplain in 1997, the regeneration was completed within 2 years. Woody plant species were less affected by the 1997 flood except Euonymus europaeus and Sambucus nigra which died down as well. One month after water regression 28 species were already recorded, regenerating from underground organs or from the present seed bank e.g. Alopecurus pratensis, Carex gracilis, Carex riparia, Dactylis glomerata, Elytrigia repens, Iris pseudacorus, Juncus effusus, Lysimachia nummularia, Lysimachia vulgaris, Lythrum salicaria, Phalaris arundinacea, Polygonum amphibium, Potentilla anserina, Potentilla reptans, Rorippa sylvestris, Rumex crispus, Sanguisorba officinalis and there was also a massive occurrence of seedlings of Plantago lanceolata. Woody plant species seedlings except Fraxinus excelsior were absent. Three month after flooding vegetation cover increased up to $60 \%$. Vegetation was still absent in deep depressions where water stagnated longer time. The following growing season the vegetation cover in these depressions reached half of the vegetation cover in the surroundings and the next year there was no notable difference in vegetation cover.

Kovár et al. (2002b) also concluded that the regeneration of floodplain vegetation after extreme floods was successful even on places that were buried under layer of sediments. Geophytes were especially successful 
followed by Alopecurus pratensis, Poa pratensis, Rumex acetosa, Rumex obtusifolius, Symphytum officinale, Plantago lanceolata.

Generally the regeneration of native floodplain vegetation is fast since species have evolved life strategies that enable them to quickly colonize large areas. The ability of certain species to regenerate depends mainly on the depth of flood water, duration of flooding and thickness of sediment. Flood induced dynamics within vegetation communities creates series of patches with following characteristics:

- the vegetation community does not change, the flood causes only fluctuation in overall vegetation cover

- the vegetation community does not change, the flood causes only fluctuation in vegetation cover of dominant species

- the temporal change in composition of the vegetation community but the development leads towards previous state

- the long term change in composition of the vegetation community.

\subsection{Vegetation succession on new sites and on agricultural land abandoned due to floods}

On newly deposited sediment the composition of species is dependent upon several factors. Primarily it is dependent upon the seed bank brought and deposited together with the sediment but also on the seed bank buried underneath. The succession is afterwards controlled mainly by abiotic factors such as the type of sediment in terms of coarseness, insolation, the amount of organic matter and also the microclimate. The vegetation succession may be also influenced by the layer of nutrient rich fluvisols under sediments that can be easily accessible to plant roots.

The diversity of seed bank contained in the sediment reflects the timing of flooding. According to Kovár at al. (2002b) the diversity of seed bank is recognizable already one month after flooding during the growing season. Kovár et al. (2002a) and Janoušková (2001) also concluded that the seed bank was not large in deposits and there was no difference between sand and gravel despite the sandy sediments were previously thought to contain richer seed bank. The most common species of the deposits were Urtica dioica, Stellaria media, Artemisia vulgaris, Chenopodium album, Chenopodium polyspermum, generally species producing high number of seeds. There also occurred new species, after the floods, previously absent it the Orlice river floodplain e.g. Melandrium rubrum, Aster novi-belgii, Sedum hispanicum, Rudbeckia laciniata or Veronica filiformis. Patches covered by sediments represent places with minimal space and light competition, therefore these conditions enable establishment of less competitive species.

Blažková (2003) studied the vegetation succession on deposits in the Berounka river floodplain after the floods in 2002. Massive gravel sediments were without vegetation even two month after water regression compared to gravel sediments with layer of sand underneath where species from the alliance Bidention and mainly ruderal plant species had already been present. The most common young seedlings were Galium aparine, Stelaria media, Carduus crispus, Barbarea vulgaris and Rumex obtusifolius. Sandy and less coarse gravel sediments were the most vegetated sediments two month after floods. The most common species were Sinapis alba and Triticum aestivum that were brought from the surrounding agricultural fields with the sediments. 
Loamy sediments were deposited only in higher parts of the floodplain. They did not cause any damage to the present vegetation but they enriched the sites with nutrients and moisture, moreover enriched the seedbank with several species e.g. Potentilla supina, Veronica beccabunga, Filaginella uliginosa.

Blažková (2003) also recorded vegetation of erosive cuts that occurred only in those parts of floodplains converted to arable land. The most common species were Equisetum arvense and ruderal plants.

Generally we can summarize the knowledge about vegetation succession on sediment as follows:

- annual plants are the first colonists followed by plants expanding from sides

- there is a higher biodiversity on new sediments compared to the surroundings e.g. Blažková (2003) recorded 50 species within a $25 \mathrm{~m} 2$ plot

- there can occur plant species long time absent in the floodplain or mountain and submountain species can occur in the lowland

- the sediments can support expansion of invasive species or support less competitive species

- the full canopy closure occurs after 2 years on sandy sediments, and after 4 years on gravel sediments; the difference is due to different amount of organic matter and different moisture regime

- the regular rhythm of more extensive floods maintains the sediments in early successional stages.

Kováŕ (1998) and Kovár et al. (2002a) studied the succession of vegetation after floods in 1997 in the Morava river floodplain. The agricultural land abandoned due to the floods was dominated by invasive plant species e.g. Solidago gigantea, Impatiens glandulifera and woody plant species e.g. Salix triandra, Salix purpurea, Salix caprea, Alnus glutinosa. The willows colonized mainly depressions while alder mainly more coarse sediments. The common woody plant species were also Betula pendula, Populus tremula, Acer pseudoplatanus. Five years after floods the mosaic of herbal, shrub and potentially forest stages of succession were present. The same conclusions brought also the research in the Bečva river floodplain after the floods in 1997. The 1997 flood renewed ecological conditions suitable for floodplain forest that was destroyed during former channel modifications. The similar succession stages were identified also in several other floodplains affected by the 1997 flood e.g. the rivers Desná, Branná and Krupá.

\subsection{Spreading of invasive species in floodplains}

The areas affected by fluvial disturbance offer possibility to be colonized by invasive neophytes (introduced species that rapidly occupy new areas). There are more reasons for successful spreading of invasive neophytes in river floodplains. These are the most important of them:

- floodplain is an extraordinary dynamic and overburdened area

- river is something like "transport trunk" of material and energy flows in the landscape; it makes opportunity for rapid spread of introduced species diaspores

- there is an extraordinary concentration of human settlement and economic activities; the spread of invasive species is supported especially by transport and agricultural activities

- floodplains are often degraded due to an extraordinary high level of anthropogenic pressures 
- there is regular disturbance of these areas by floods

- floodplain soils are very nourishing.

The most important invasive plants in floodplains and river bank vegetation in Czechia are Reynoutria japonica, $R$. sachalinensis and $R . \times$ bohemica, Solidago gigantea, $S$. canadensis, Helianthus tuberosus, Impatiens glandulifera and others. This species can be important competitors for native species and they can form large monocultural areas. For example, more than $1 \%$ from the total area of Prrerov town region (Central Moravia) is covered by invasive species, especially in Bečva river floodplain (Dohnal 2005).

These species can also change their own habitat. For example, the rootage of Reynoutria can destabilize and destroy river banks. Other species can hybridize with natives. This process can make native species disappear. Another interesting example from floodplains in Czechia is Populus $\times$ canadensis. It is a hybrid of native Populus nigra and Populus deltoides, which was introduced there. Although it was rather frequent in history, the pure form of Populus nigra ssp. nigra is very rare now. There are only about 200 individuals in Czechia now (for further information see Benetka 1997).

The spreading of invasive species in certain sections of floodplains affected by floods was in Czechia studied for example by Kopecký (1967), Lacina et al. (1998), Kovář et al. (2002a), Kováŕ (2002) and Blažková (2003).

A large expansion of Impatiens glandulifera and Solidago sp. was observed in Moravia after floods and a large expansion of Bunias orientalis and Impatiens glandulifera in the Tichá Orlice river floodplain. Impatiens glandulifera appeared in the Orlice river floodplain in 1970's and 1980's. Indian balsam became dominant species of river bank vegetation during this time period and after floods in July 1997 it rapidly occupied all the floodplain area. It was spreading from fresh fluvial sediments to the upper and drier grassland, forest edges and it also occupied partly the sunny forest borders out of floodplain. The spreading was not so successful in coherent areas of Urtica dioica. Bunias orientalis was found to be successful competitor to perennial coherent vegetation. It normally produces seeds there and it is able to regenerate from underground organs (Kovár̆ et al. 2002b).

On the other hand, Lacina et al. (1998) presents rather different results from the Bečva river floodplain. There were scatterly observed invasive neophytes only during initial succession states, in spite of their long term previous presence in neighbor river bank vegetation before floods. Reynoutria japonica, Helianthus tuberosus and Impatiens glandulifera were found only on newly established habitats after floods having formed scattered isles there (Lacina et al. 1998).

The population of Impatiens glandulifera in Berounka river floodplain was quite reduced by floods in July 2002 . There were found only 2 individuals there after these floods, but the seeds of Indian balsam were distributed by water along the entire river. On the other hand, Echynocystis lobata did not lose its position after the floods. Reynoutria japonica was after the floods successful too and there was found a great number of regenerating individuals there in October 2002 (Blažková 2003).

Kopecký (1967) observed rapid spreading of Solidago sp. and Impatiens glandulifera on the central and lower section of the Bečva river. This species were spreading there due to regulation of the river and devastation of natural river bank phytocoenosis.

There was observed a low number of invasive neophytes, especially of Reynoutria sp., Impatiens glandulifera and Solidago sp. in the floodplains of the rivers Blanice and Volyňka in the south of Bohemia, in comparation with 
the situation in the floodplains of both the Orlice river and rivers in the north of Moravia. However, this difference had already been there before the floods.

The massive spreading Impatiens glandulifera was already observed in floodplains of both Tichá and Divoká Orlice rivers in 1990's. (Lipský et al. 1993). This species spreads rapidly in floodplains of the other rivers (for example, Sázava, Svratka and its tributaries under the Vír Lake. It has been spreading also in the parts that have not been affected by floods during last decades.

Helianthus tuberosus spreads especially in Moravian river floodplains. Two thirds of areas affected by invasive neophytes in Přerov town region were formed by this species (Dohnal 2005).

The situation of different biotopes in the central Labe floodplain (between towns Kolín and Čelákovice) was studied in 2004 (Matějček 2004). Since there were no great floods in this part of Labe river floodplain in last decades, it is interesting to compare it with the river floodplains affected by great floods during last years. There was observed relatively lower occurence of Reynoutria sp. and Impatiens gladulifera in the Labe floodplain if we compare it with the other rivers in the Czech Republic, but the abundance of Solidago $s p$. is rather high. Impatiens parviflora were observed to be very common in floodplain forests, it was often dominant species of bottom layer. High number of invasive species was observed in exhausted send quarries. In addition to current invasive species mentioned before there was also observed rather high occurrence of Erigeron annuus.

Of course, the spreading of invasive species is not a problem only of the Czech rivers. There were, for example, observed Reynoutria japonica, Solidago gigantea, Acer negundo) and Robinia pseudacacia in the Rhôna river floodplain (Schnitzler et al. 2005). The most important invasive species of river floodplains in Ireland are Impatiens gladulifera, Reynoutria japonica and especially rhododendrons (most often it is a hybrid of Rhododendron ponticum and Rhododendron catawbiense (Pilcher, Hall 2001).

\section{Conclusion}

Extreme floods are an integral part of floodplain ecosystem and a significant driver influencing its dynamics and the whole development. They disturb existing habitats, create new ones and support a varied mosaic of different habitats with different successional stages of vegetation. Floodplain vegetation is adapted to floods as repeated stress factor and after floods the vegetation is capable to regenerate. In general the ability to regenerate is dependent upon flood duration and flood water depth. On localities where new morphological landforms like gravel beds and sand deposits were formed the spontaneous succession is initiated. Therefore vegetation communities create a series of patches made up transitions between more or less stable stands in the floodplain. Different successional stages as well as variable habitats in floodplains are functioning as factors increasing ecosystem and species biodiversity. According to the basic landscape ecological principle on the role of disturbances in the landscape (Forman, Godron 1993), repeated floods necessitate an increased geo/biodiversity in the riverine landscape.

Because of the close dependence on natural flooding regimes, floodplains are particularly vulnerable ecosystems and any anthropogenic alterations of hydrology and vegetation can modify the ecosystem in a significant way. Moreover floodplains were proofed to be important sources of biodiversity in the 
landscape. Factors controlling the diversity, species composition and development of the vegetation can be divided into 5 groups: geographical factors (especially morphological and geological conditions); flood duration, frequency, intensity and timing; dominant species in vegetation; disturbances caused by large mammals and floodplain history in the sense of anthropogenic alterations.

Disturbance regime of floods and erosion of existing vegetation communities offer, on the other hand, an excellent possibility for the disturbed sites to be colonized by invasive neophytes that spread rapidly through floodplain. Field research carried out on more Czech and Moravian rivers after catastrophic summer floods in July 1997 and August 2002 confirmed big differences in occurring invasive plant species in different areas. While future spatial distribution and spread of invasive species is difficult to forecast, the processes of succession and regeneration of vegetation after floods are well predictable.

\section{References:}

AMOROS, C. et al. (1987): The reversible process concept applied to the environmental management of large river systems. Environmental Management, 11, pp. 607-617.

BALÁTOVÁ-TULÁČKOVÁ, E. (1996): K ekologii zaplavovaných luk kontinentálně laděných oblastí. Př́roda, 4, AOPK, Praha, pp. 69-76.

BAILEY, P. B. (1995): Understanding large river-floodplain ecosystems. Biological Science, 45, pp. $153-158$.

BENETKA, V. (1997): Program na záchranu genofondu topolu černého v České republice. Ochrana prrírody, 52 , No. 6, pp. 178-180.

BLAŽKOVÁ, D. (1996): Aluviální louky řeky Berounky. Příroda, 4, AOPK, Praha, pp. 125-129.

BLAŽKOVÁ, D. (2003): Pobřežní vegetace řeky Berounky dva měsíce po povodni v srpnu 2002. Bohemia centralis, 26, Praha, pp. 35-44.

BROOKS, A. P., BRIERLY, G. J., MILLAR, R. G. (2003): The long-term control of vegetation and woody debris on channel and floodplain evolution: insights from a paired catchment study in southeastern Australia. Geomorphology, 51, pp. 7-29.

DOHNAL, J. (2005): Evidence výskytu neofytů na území Přerova a návrh na jejich likvidaci. Absolventská práce. VOŠ zahradnická, Mělník, 57 p.

FORMAN, R. T. T, GODRON, M. (1993): Krajinná ekologie. Academia, Praha, 586 p.

HADINCOVÁ, V. (1996): Vodní retenční kapacita půd nivních luk. Př́roda, 4, pp. 53-66.

HOLOUBEK, I., DUŠEK, L. et al. (1998): Identifikace rizik pro životní prostředí. Projekt IDRIS. Výzkumná zpráva MR/340/1/96 depon. in knih. CENIA.

HUPP, C. R. (1992): Riparian vegetation recovery patterns following stream channelization: a geomorphic perspective. Ecology, 73, pp. 1209-1226.

HUPP, C. R., OSTRKAMP, W. R. (1996): Riparian vegetation and fluvial geomorphic processes. Geomorphology, 14, pp. 277-295.

JANOUŠKOVÁ, P. (2001): Ekologický význam náplavů v ř́iční nivě. Thesis. Depon. in Knih. kat. bot. PřF UK, Praha.

KENYON, CH., RUTHERFORD, I. D. (1999): Preliminary evidence for pollen as an indicator of recent floodplain accumulation rates and vegetation changes: The BarmahMillewa forest, SE Australia. Environmental Management, 24, No. 3, pp. 359-367.

KOLEJKA, J. (2003): Geoekologické aspekty zmírňování povodňových škod. Geografie-Sborník ČGS, 108, No. 3, pp. 1-13.

KOPECKÝ, K. (1969): Změny druhového složení některých fytocenos v inundaci dolního toku Orlice po záplavách v roce 1965. Preslia, 4, pp. 284-296.

KOPPOVÁ, J. (2001): Znovuosidlování náplavů vegetací na aluviálních loukách. Thesis. Depon. in Knih. kat. bot. PřF UK, Praha.

KOUTECKÝ, P. (2000): Regenerace luk v nivě Moravy po katastrofální povodni v roce 1997. Thesis. Depon. in knih. kat. bot. PřF UK, Praha.

KOUTECKÝ, P. (2003): Změny vegetace aluviálních luk po povodních (jižní Morava). Zprávy ČBS, 38, pp. 111-115. 
KOVÁ̌̌́, P. (1998): Povodňové náplavy: otevřený biologický prostor. Živa, 84, No. 5, p. 203-204.

KOVÁR̆, P. (2002): Ekologická synchronie: paralelní koridory v krajině a rostliny (Případová studie: Bunias orientalis L. v polokulturní krajině ř́iční nivy). In: Maděra P. (ed.): Ekologické sítě. Sborník příspěvků z mezinárodní konference 23.-24.11.2001 v Brně, Geobiocenologické spisy, sv. 6, MZLU v Brně a Mze Praha, pp. 14-18.

KOVÁR̆, P. (2003): Transplantovaná synantropizace: rostliny a nová stanoviště vložená do krajiny. Zprávy ČBS, 38, pp. 17-26.

KOVÁR̆, P. et al. (2002a): Ekologický význam vegetační sukcese v říční nivě po extrémních záplavách. Souhrn dosažených výsledků, Projekt GAUK126/2000/B/BIO, PřF UK, Praha.

KOVÁR̆, P. et al. (2002b): Vegetační sukcese v nivě řeky pět let po záplavě. Živa, 88, No. 6 , pp. 253-257.

KRAHULEC, F. (1996): Př́ičiny druhové diverzity aluviálních luk a možnosti jejich obnovy. In: Př́roda, 4, AOPK, Praha, pp. 155-162.

KVĚT, J. (1996): Obecné ekologické funkce nivních luk. Příroda, 4, AOPK, Praha, pp. 21-23.

LACINA, J. (2002): Katastrofické př́rodní jevy a jejich odezva v ochraně přírody a krajiny. In: Tvář naší země. Krajina domova. Díl 5. Ochrana krajiny. Studio JB, Praha, pp. 37-43.

LACINA, J. et al. (1998): Sledování sukcese, vegetace a vývoje říčního koryta ve vybraných profilech Bečvy mezi Osekem n. B. a Valašským Meziříčím. Výzkumná zpráva, Ústav geoniky AV ČR, Brno, 61 p.

LANGHAMMER, J. et al. (2006): Změny krajiny jako ovlivňující faktor průběhu a projevů extrémních povodní. PřF Uk, Praha, 209 p.

LIPSKÝ, Z. et al. (1993): Ekologická studie Orlice. ÚAE VŠZ, Kostelec n. Č. 1. Studie pro Povodí Labe.

LOŽEK, V. (2003): Povodně a život nivy. Bohemia centralis, 26, Praha, pp. 9-24.

MARSTON, R. A. el al. (1995): Channel metamorphosis, floodplain disturbance and vegetation development: Ain River, France. Geomorphology, 13, pp. 121-131.

MATEJČEK, T. (2004): Invazní druhy rostlin v nivě středního Labe. In: Měkotová, J., Štěrba, O. (eds.): Sborník z konference Říční krajina, PřF UP, Olomouc, pp. 162-167.

MEYER, G. (2001): Recent large-magnitude floods and their impact on valley floor environments of northeastern Yellowstone. Geomorphology, 40, pp. 271-290.

PETIT, N. E., FROEND, R. H. (2001): Variability in flood disturbance and the impact on riparian tree recruitment in two contrasting river systems, Wetland Ecology and Management, 9, pp. 13-25.

PETŘÍČEK, V. (1998): Povodně v nivách a náprava jejich účinků na krajinu. Živa, 84, No. 4, pp. 154-156.

PILCHER, J., HALL, V. (2001): Flora Hibernica. The wild flowers, plants and trees of Ireland. The Collins Press, Cork, 203 p.

RYCHNOVSKÁ, M. (1992): Funkčnost a vzájemné vztahy polopřirozených a umělých ekosystémů v říční nivě. CHKO Litovelské Pomoraví. Výzkumná zpráva F1.14/01 depon. in Knih. CENIA.

RYCHNOVSKÁ, M. (1996): Ekosystémové funkce nivních luk. In: Příroda, 4, AOPK, Praha, pp. 25-33.

SALO, J. el al. (1986): River dynamics and the diversity of Amazon lowland forest. Nature, 332 , pp. 254-258.

SCHNITZLER, A., HALE, B. W., ALSUM, E. (2005): Biodiversity of floodplain forests in Europe and eastern North America: a comparative study of the Rhine and Mississippi Valleys. Biodiversity and Conservation, 14, pp. 97-117.

TOWNSEND, P. A. (2001): Relationship between vegetation patterns and hydroperiod on the Roanroke River floodplain, North Carolina. Plant Ecology, 156, pp. 43-58.

VANĚČEK, Z. (2005): Sukcese vegetace na říčních náplavech vzniklých po povodni v srpnu 2002. Bakalářská práce depon. in Knih. kat. bot. BF JU, České Budějovice.

\section{Shrnutí}

\section{SUKCESE VEGETACE V ALUVIÁLNÍCH ZÁPLAVOVÝCH ÚZEMÍCH PO EXTRÉMNÍCH POVODNÍCH}

Extrémní povodně jsou neoddělitelnou součástí nivních ekosystémů a jsou významnou řídící silou, která ovlivňuje dynamiku a celý vývoj říčních niv. Disturbanční režim povodní 
vede $\mathrm{k}$ vytvářrení nových stanovište, na nichž probíhají intenzivní procesy ekologické sukcese a kolonizace. Povodně tak přispívají k rozrůznění ekosystémů a tím i ke zvyšování biotické pestrosti společenstev v údolní nivě. Nivy řek představují složitý přirozeně fragmentovaný ekosystém, jehož stav v sobě vstřebává a odráží vliv historických i současných př́írodních disturbancí (záplavy, eroze, sedimentace), klimatických faktorů a managementu. Mimořádná rychlost a intenzita geomorfologických procesů eroze, transportu a sedimentace je doprovázena procesy sukcese, kolonizace a migrace druhů. Tuto vlastnost si ponechávají i nivy v kulturní krajině pozměněné a využívané člověkem. Nivy tak slouží jako významné koridory pro pohyb rostlinných a živočišných organismů a také jako prostory š́ŕrení invazních druhů v krajině. $\mathrm{K}$ jejich šíření obecně přispívají disturbance, které způsobují narušení ekosystémů a vytvářejí nová stanoviště, jež jsou často obsazována invazními druhy. Vegetace niv je navíc závislá na dostupnosti diaspor, populační dynamice druhů a jejich ekologických nárocích.

Katastrofální povodně, které se v posledních 10 letech opakovaně vyskytly na rozsáhlých územích Česka, byly impulsem pro celou řadu případových studií, zabývajících se sledováním změn vegetace $\mathrm{v}$ územích postižených záplavou a sedimentací. Údolní nivy jako periodicky narušovaná území tak představují jakési terénní laboratoře, v nichž lze sledovat průběh sukcese, osídlování nově vzniklého nebo narušeného prostředí, změny v druhovém složení společenstev a další ekologické procesy v krajině. Tematické zaměření dosavadních výzkumů lze rozdělit do 3 skupin:

- regenerace původní vegetace po narušení způsobeném povodní

- sukcese na nově vytvořených stanovištích

- šíření invazních druhů rostlin v údolní nivě.

Nivní vegetace má vyvinutou řadu adaptačních mechanismů a dokáže na působení disturbancí způsobených povodní spontánně reagovat. Záplavy eliminují výskyt druhů, které $\mathrm{k}$ nim nejsou přizpůsobeny, podporují druhy přizpůsobené a umožňují i existenci některých konkurenčně slabších druhư. Schopnost regenerace vegetace po záplavách závisí především na délce trvání povodně a na jejich extremitě (výšce maximálního vodního stavu). Tam, kde v důsledku povodní vznikly nové geomorfologické tvary (např. štěrkopískové akumulace), dochází ke spontánní sukcesi. Vytváří se tak pestrá mozaika vegetace v různých sukcesních stádiích.

Vývoj nivní vegetace, její prostorové rozmístění a druhovou diverzitu ovlivňují nejrůznější faktory, které je možno rozdělit do pěti skupin: geografické faktory (především geologické a geomorfologické podmínky); frekvence, intenzita a délka trvání záplav; dominantní druhy; disturbance způsobené působením velkých savců a historický vývoj nivy, především její antropogenní ovlivnění.

Pravidelné disturbance a vznik nových stanovišt však na druhou stranu vytvářejí podmínky pro šíření invazních druhů, které může být příčinou poklesu početnosti populací druhů domácích. Významným praktickým problémem je navíc špatná předvídatelnost působení invazních druhů v nově obsazených ekosystémech. $\mathrm{V}$ údolních nivách řek a jejich břehových porostech se $\mathrm{v}$ uplynulých desetiletích rozšiŕily zejména kř́ldatky (Reynoutria japonica, $R$. sachalinensis a $R$. $x$ bohemica), zlatobýly (Solidago gigantea a $S$. canadensis), slunečnice hlíznatá (Helianthus tuberosus), netýkavka žláznatá (Impatiens glandulifera) a některé další. Mezi jednotlivými řekami postiženými katastrofálními záplavami však existují ve výskytu invazních druhů významné rozdíly.

Výsledky výzkumů prováděných na mnoha českých, moravských a slezských řekách postižených katastrofálními povodněmi v červenci 1997 a v srpnu 2002 přinesly zajímavé poznatky o průběhu sukcese a kolonizace na narušených nebo nově vytvořených stanovištích. Potvrdily také rozdíly $\mathrm{v}$ charakteru a průběhu těchto procesů mezi vodními toky horských a podhorských či nížinatých oblastí, které vyplývají zřejmě z rozdílného charakteru sedimentace $\mathrm{v}$ údolní nivě i $\mathrm{z}$ rozdílů v okolní krajině, v množství a typu genetického materiálu apod. Další výzkumy $\mathrm{v}$ modelových územích by měly přispět $\mathrm{k}$ vysvětlení těchto rozdílů a zákonitostí.

Obr. 1 - Faktory ovlivňující vegetaci v záplavových územích

(Authors are with Charles University in Prague, Faculty of Science, Department of Physical Geography and Geoecology, Department of Social Geography and Regional Development, Albertov 6, 12843 Praha 2, Czechia; e-mail: chumant@natur.cuni.cz, lipsky@natur.cuni.cz, tomatej@natur.cuni.cz.) 